\title{
Geographic Information System for Booking Beauty Salon and Barber Shop with an Android-Based ECRM Approach
}

\author{
I Kadek Dharma Krisna Putra ${ }^{1}$, I Nyoman Piarsa ${ }^{2}$, I Made Sukarsa ${ }^{3}$ \\ ${ }^{1,2,3}$ Departement of Information Technology, Faculty of Engineering, Udayana University, Indonesia \\ Email: ${ }^{1}$ dharmakrisna.dk@gmail.com, ${ }^{2}$ manpits@unud.ac.id, ${ }^{3}$ sukarsa@unud.ac.id
}

\begin{abstract}
Beauty salons and barbershop are a necessity for almost everyone. Nowadays, the business processes of them mostly still use conventional methods. The method gives obstacles to customers who have a lot of activities, for example, they have to come directly to the beauty salon or barbershop to take the queue. In addition, it is hard to promote, communicate, and assess without E-CRM media. The location is also difficult to find because there is no guiding mark on Google Maps. The Geographic Information System for Booking Beauty Salon and Barber Shop provides solutions for making scheduled bookings and transactions by using the e-CRM approach as in the application of promotional features to attract customers. There are some features offered in the application, such as chat features for communication, rating, and review feature to assess the services obtained, and route feature as a solution to show the location of selected vendors. The implementation process requires an Android smartphone and a computer device with software including Android Studio, SQLYog, XAMPP, and Visual Studio Code. The results of the implementation of the system based on the questionnaire showed $25.8 \%$ answered 'excellent', $45.7 \%$ answered 'good', $28.3 \%$ answered 'enough', and $0.2 \%$ answered 'bad'.
\end{abstract}

Keywords: Geographic Information Systems, Booking, Promotion, E-CRM, Android

\section{INTRODUCTION}

A beauty salon is a place for hair care and makeup that generally serves female customers, while barbershop is a place for hair, mustache, or beard care that serves male customers. The numbers of service providers make it difficult for customers to make choices in finding a suiTable one. This is also caused by not establishing a good relationship between service providers and service users, for example, the incompatibility of promotional services offered, service quality, and price offered. This need is trying to be accommodated by providing information systems to facilitate interactions between users and service providers that include bookings, promotions, transactions, chatting features that can be accessed using an Android device. This system is implemented by an E-CRM approach that prioritizes customer satisfaction and loyalty. There are several features offered by this system, for example, the implementation of a payment system with an electronic wallet model that can be refilled as a means of payment, the availability of chat features to communicate directly with service providers, there are rating and review features 
to get an overview of service quality provided or as an assessment of services provided, and customers can also use promotions provided by service providers.

There are several studies used as references in the recent study to produce solutions related to online ordering, GIS, and CRM. A research conducted by I Putu Warma Putra produced an application that facilitates customers in ordering a taxi and assisting the driver in picking up a customer. Some of the steps conducted are system analysis, system design, and system implementation [1].

Yuwono, Aribowo, and Setyawan conducted research that developed a geographic information system for tourism in the Magelang area based on Android. The system can be connected directly with Google Maps. The result is the system can provide information about tourism location in the Magelang area easily because it can be operated wherever the user's location is. Therefore, this result is in accordance with the purpose of the developed application. Overall, the application successfully provides tourism information and the best tourism location from the user's position [2]. Yunefri, Devega and Kristanto developed a web-based GIS application with the aim of providing information about culinary in Pekanbaru based on the user's location. The development of the application is carried out by using the PHP programming language and the Haversine method to determine the closest distance of a restaurant. The results of the obtained data were tested by using a black box to show that a test by using this application is similar to the manual method [3].

A research conducted by Neene and Kabemba is the expansion of a property mapping application with a geographic information system that can be used by local authorities in developing countries. The result of this study showed this application did not require the acquisition of attribute, spatial, and real-time image data from properties. The study was strengthened by conducting a survey on the Kafue local authority to meet the requirements needed by the system. After designing and modeling, the developed system was tested on the field with the results of 10 properties were successfully mapped [4]. A research conducted by Kusnawi discussed ordering problems that cause inconvenience to customers, such as running out of seats and also uncertainty. This problem is trying to be solved by providing a Table and food ordering information system and placing it on the main server of a desktop-based restaurant. The results can be developed into web and desktop applications. The desktop application is a medium to verify online orders made by customers via the web, therefore, different platform's orders can still be entered and verified. This system supports the use of balances that can be topped up as a means of payment [5].

Aulia Aulia, Zakir, Dafitri, Siregar, \& Hasdiana conducted research that related to the situation in the restaurant. This study designed a system that can speed up ordering and food processing in restaurants. The results of this study also allow ordering data to be sent over a wireless network that connects smartphones to 
computers in the kitchen. As a result, the order can be directly read by the chef because it is shown on the LCD screen [6].

A research conducted by Rosadi and Andriawan developed an Android-based system that can facilitate in finding boarding houses from certain areas and also promote boarding houses found in the city of Bandung. The methods used in this research are descriptive analysis and development, data collection methods, and object-oriented system development methods. The results of this study indicate that an application for a boarding house can facilitate users in obtaining information, therefore the users can find boarding houses easily and according to their criteria [7].

A research conducted by Mila Afrina and Ali Ibrahim used the E-CRM concept. It resulted in a strategy to obtain, consolidate, and analyze data to be used to interact with customers (students, students, teachers, lecturers, and the community). Thus, a comprehensive view of the customer and a better relationship with the customer are created [8]. A research conducted by Le-Tan discusses the progress of information technology. Thereby, it drives changes in consumer behavior in shopping, especially in e-commerce. The results obtained are indicators of the success of eCRM implementation in e-commerce companies. This research uses a descriptive method with the Library Research approach by looking at several previous journals and using three indicators: customer complaints, customer loyalty, and management control of e-CRM implementation. The result is that these indicators can be used as a benchmark in determining the level of success in implementing e-CRM in e-commerce [9].

A research conducted by Tamara Luarasi, Andi Domi, Tomi Thomo, Agim Kasaj, and Ergon Baboci explained that the latest technology has supported the latest business scenarios and the application of existing ones. Its application has been tested on the livestock market, which is in dire need of the presence of technology, especially in difficult rural zones. This study represents the method used in making digital brokers [10].

Neny Rosmawarni developed a system that provides recommendations for application development. This study uses a collaborative filtering method, where the data is taken based on user feedback such as reviews and ratings. This application is an Android-based and was tested in the field of beauty like a beauty salon. With some recommendations from this application, the users can consider a beauty salon that matches their needs, budget, and the suitability of the type of care provided based on the needs of the user [11].

An information system with the implementation of web-based customer relationship management $(\mathrm{CRM})$ is the final result of research conducted by Tukino. It can be used to manage customer complaints with PT Indoritel Makmur International Tbk (Indomaret) Batam as the case study. The method used is 
Extreme Programming which is the most widely used approach for developing this software. The results of this study are CRM information systems with a web platform [12].

Irvan Prastya, Sarip Hidayatuloh, and Nidaul Hasanati conducted research by designing a website-based E-CRM information system at PT Persada Duta Beliton. It can be used for maintaining company relationships with customers. The results of this study are the system has a tour package booking feature, a chat feature for customer communication, and a feature for giving tours package reviews based on customer experience. In addition, there is a promotional media for the customer, such as congratulating a celebration by giving gifts in the form of discounts to them. The model in developing the system is the Rapid Application System (RAD). The system design is conducted with UML [13].

Anharudin, Donny Fernando, and Novi Khristina Putri developed an E-Booking Information System that can be used to facilitate customers to order karaoke rooms at Happy Puppy in Cilegon City. The application is developed and designed by using UML modeling. In addition, it is created with the PHP programming language and uses MySQL to store the database. The existence of an E-Booking Information System is expected to help customers in ordering karaoke rooms at Happy Puppy in Cilegon City, Banten [14].

A research conducted by Devi Mawarni and Rinabi Tanamal developed an information system for a medium scale beauty salon by using Visual Basic 2010 programming with SDLC waterfall. The study was conducted by interviews to obtain and conduct data analysis. The implementation resulted in a program that could solve the problems found in medium-scale beauty salons [15].

Research conducted by Luh Gede Sri Handayani, I Nyoman Piarsa, Kadek Suar Wibawa produced a geographic information system for web-based village road mapping. This system using Google Maps, with the polyline feature making it possible to describe the road network and geometry library that can calculate road lengths. Data collection on this system is done in two ways, digitizing and input coordinates, and processing data on master data. The results of this mapping provide information on road names, types of road surfaces, road lengths, and road conditions [16].

Research conducted by I Made Widnyana, I Nyoman Piarsa, A. A. K. Agung Cahyawan $\mathrm{W}$ developed a geographic information system to map the location of workshops in Denpasar. This system can be accessed using an Android smartphone with Google Maps API support that allows the user to find out information about the workshop. The results of this study are the application can allow users to get route information with the direction feature. Users can see detailed information 
about services and spare parts provided by the workshop. For the workshop, owners can update service information and create promos [17].

Research by I Wayan Wahyu Gautama, I Ketut Gede Darma Putra, I Made Sukarsa produced a geographic information system for mapping coastal tourism objects in southern Bali. This application is designed using the Google Maps API which can be run on android devices. The test results obtained a percentage of $80 \%$ with a very good value in terms of the presentation of content and beach information, this application can also display the route to the beach [18].

Based on the background and references above, this research focuses on developing a system that facilitates interaction between the service providers of beauty salon and barbershop with customers. There is a difference in the current study with the previous one. In the previous study, there has been no solution that facilitates salon and barber users. It is because the previous study only focused on one vendor, unscheduled bookings, and the unavailability of e-CRM features such as promotions, chat, ratings, and reviews. There are some topics that still be used as supporting references in building a beauty salon and barbershop information systems such as E-CRM, booking or booking, using Google maps in GIS, and so on. This research is also expected to develop a friendly system for various vendors.

\section{METHODS}

Beauty Salon and Barber Shop Information Systems use waterfall-based lifecycle development software in designing systems. The SDLC model with the waterfall method has 5 stages in developing software, including analysis, design, implementation, testing, and maintenance. These stages can be illustrated in Figure 1.

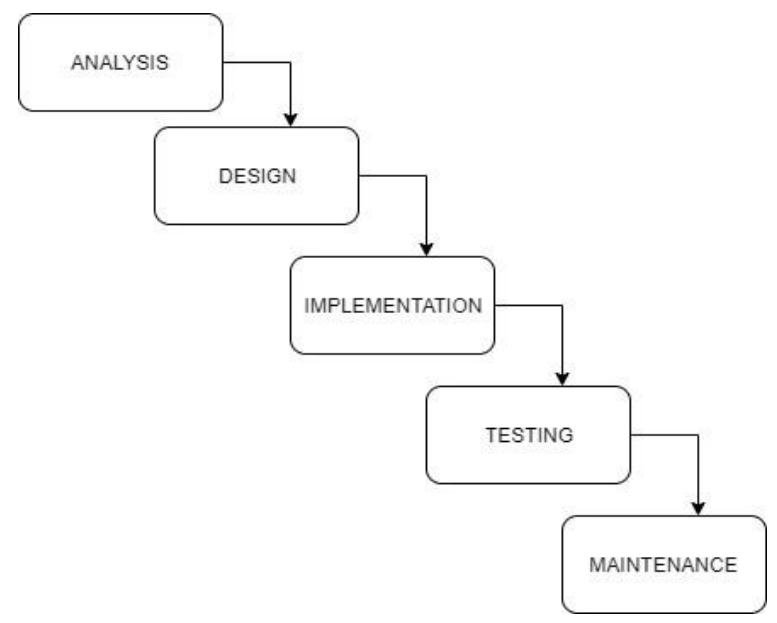

Figure 1. Stages of SDLC waterfall 
Figure 1 show the stage of system development by using the SDLC (System Development Life Cycle) waterfall method. It consists of 5 stages. The analysis is the first stage that is performed to be able to determine the needs in building and designing systems. This stage will answer all the needs of both the vendor and the customer. The second stage is designing the user interface of the beauty salon and barbershop information system. The third stage is implementing the information systems according to the needs of customers and vendors. The implementation requires several hardware devices such as smartphones and computers, while the software requires Android OS, Visual Studio Code, Android Studio, XAMPP, and Windows 10 . The fourth step is testing the system to find out the performance of it. The test was conducted to minimize errors or bugs contained in the system. If that problem happened, it can be fixed or redesigned. The fifth stage is the process of maintaining the system performance both from the internal system and errors caused by use.

\section{RESULT AND DISCUSSION}

The results and discussion on the application of the beauty salon and barbershop information systems will be explained in the form of database designs, context diagrams, and trials.

\subsection{Database Design}

The Database Design of the Beauty Salon and Barber Shop Information System is described in the form of a PDM. The PDM of the information system will be explained in Figure 2.

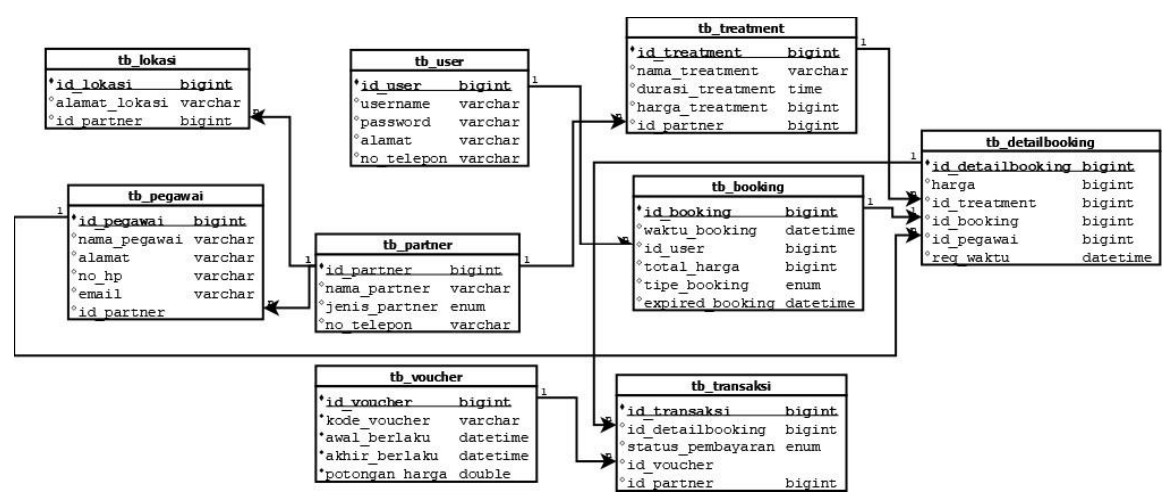

Figure 2. PDM Design

Figure 2 show a PDM of an Android-based Beauty Salon and Barber Shop Information System. There are 9 Table s that represent each entity of the database: tb_pegawai, tb_lokasi, tb_user, tb_partner, tb_voucher, tb_treatment, tb_booking, tb_detailbooking and tb_transaksi. Each of the Table or entity is equipped with data 
attributes, data types used as well as primary keys and foreign keys which determine the relationships between Tables.

Table 1. The function of the master Table in the beauty salon and barber shop booking information system

\begin{tabular}{cll}
\hline No & \multicolumn{1}{c}{ Table } & \multicolumn{1}{c}{ Function } \\
\hline 1 & Partner & Storing data information of beauty salon/barbershop partner \\
2 & User & Storing user/customer data \\
3 & Employee & Storing a partner's employee data \\
4 & Treatment & Storing a partner's treatment data \\
5 & Booking & Storing booking data \\
6 & Transaction & Storing transaction data made by customers \\
7 & Voucher & Storing voucher data used in the promo \\
\hline
\end{tabular}

\subsection{Diagram Context}

A diagram context is a diagram that consists of a process that represents the whole system. It illustrates the input or output of a system. The context diagram of the beauty salon and barbershop information system is explained in Figure 3.

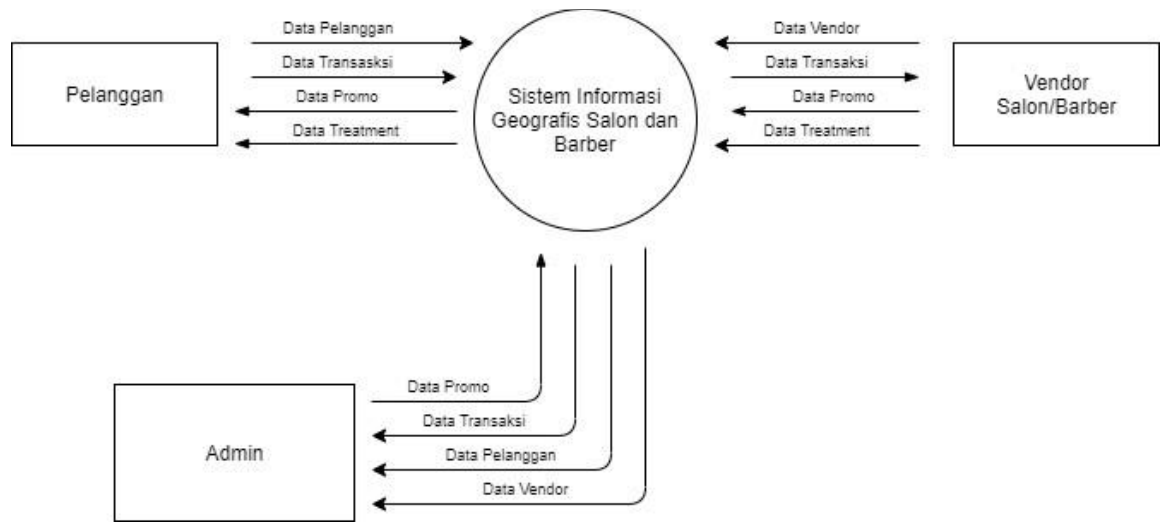

Figure 3. Diagram Context

Based on Figure 3, it can be seen that the beauty salon and barbershop information system process involves three external entities namely admin, customer, and vendor. The vendor is a service provider of the system. The system will provide and request information such as vendor data, promo data, transaction data, and treatment data provided by the beauty salon or barbershop. Customers can fill out personal data, make transactions, receive promo data, and treatment contained in the vendor. Admin manages the process of Beauty Salon and Barber Shop Information system. In addition, it plays a role as a bridge of the transaction process between the beauty salon/barbershop vendor and the user. 


\subsection{System Testing}

Testing the beauty salon and barbershop information system is conducted by testing the performance of the system directly and through the User Acceptance Testing (UAT).

\subsubsection{Application Testing}

The beauty salon and barbershop information system has two excellent features including booking features and promotional features. The booking feature is a feature that is used to order services from beauty salons and barbershops online and on schedule. The promotional features and E-CRM offer promotions and make it easier for customers to contact, rate, and review the beauty salon and barbershop.

\subsubsection{Booking Feature}

Customers can choose the treatment from each of barbershop and choose the desired time to get the service they ordered. The testing Booking feature can be seen in Figure 4.

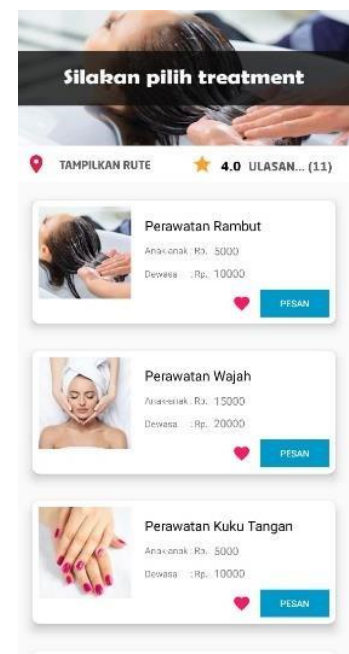

(a)

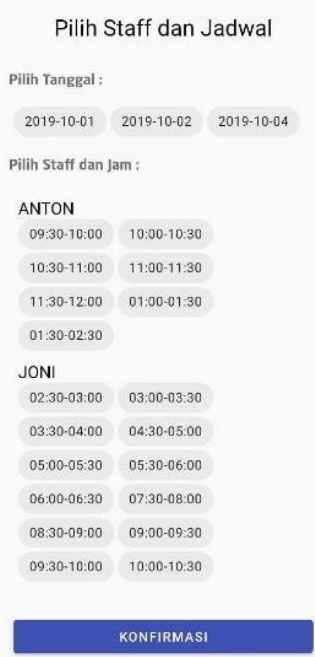

(b)

Figure 4. (a) List of salons (b) treatment selection and booking process

The customer can choose the treatment from each of registered beauty salon or barbershop in the system as shown in picture (a). Then, the customer can determine the time when they want to get the treatment and employee information from the serving vendor. The confirmation stage for incoming orders can be seen in Figure 5. 


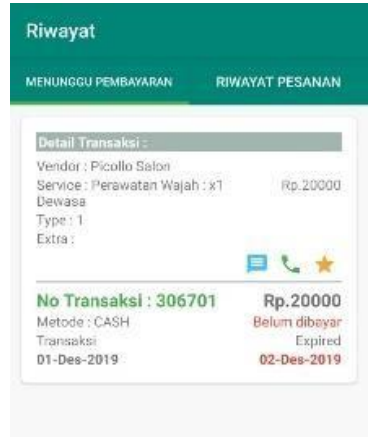

(a)

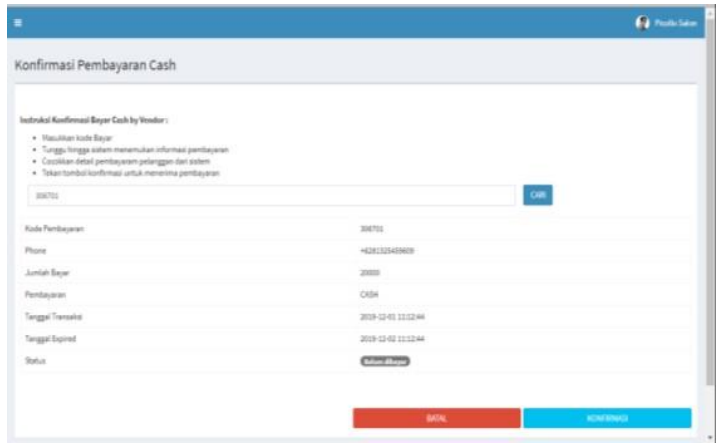

(b)

Figure 5. (a) Booking list (b) payment confirmation at the vendor

Figure (a) is a display of history when a customer has placed an order. The history shows a list of treatments that have not been paid yet and confirmed by the vendor. Figure (b) is a list of orders that will be confirmed by the vendor, therefore the customer can enjoy the treatment.

\subsubsection{Promotion Feature and E-CRM}

The promotion feature is part of implementing E-CRM on the system. Besides the promotion feature, there are chat features as well as ratings and reviews feature which are also part of the implementation of E-CRM. The testing of these features can be seen in Figure 6 and Figure 7.

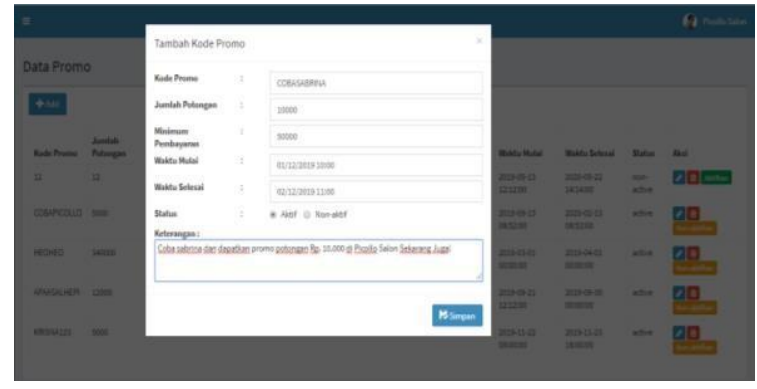

(a)

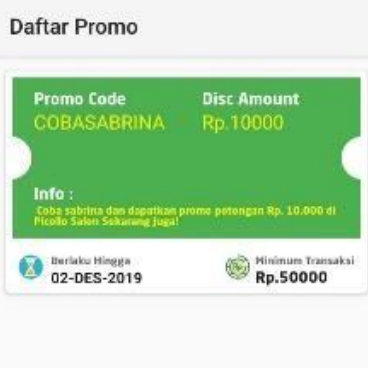

(b)

Figure 6. (a) Creating a voucher promo code at the vendor; (b) promo page

Figure 6 (a) is a feature provided for vendors in creating promotional codes. The promotional codes can be used by customers on the promo page as shown in Figure 6 (b). 


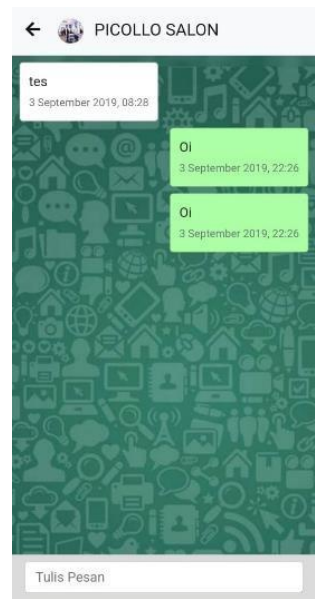

(a)

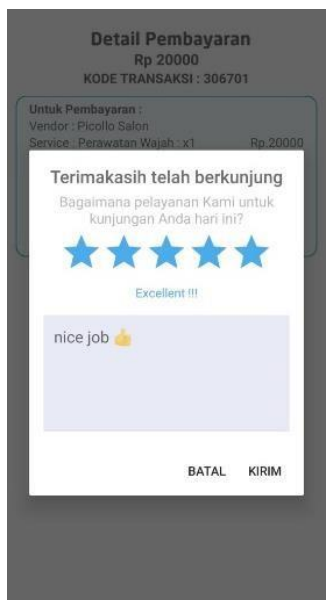

(b)

Figure 7. (a) Chatting feature; (b) Giving a review and rating

Figure 7 (a) is a chatting page provided as a communication tool between customers and vendors. Figure 7 (b) is ratings and reviews from the customers of services provided by vendors.

\subsubsection{User Acceptance Testing (UAT)}

User Acceptance Testing (UAT) is a part of testing the results of system performance based on the user's opinion and judgment. UAT questionnaire can be seen in Table 2.

Table 2. UAT Questions

\begin{tabular}{|c|c|c|}
\hline \multirow[t]{2}{*}{ No } & \multirow[t]{2}{*}{ Questions } & Rating \\
\hline & & 12345 \\
\hline 1 & $\begin{array}{l}\text { What do you think of the } \\
\text { homepage or dashboard display of the Sabrina application? }\end{array}$ & \\
\hline 2 & $\begin{array}{l}\text { What do you think of the vendor } \\
\text { and treatment selection menu display in the application? }\end{array}$ & \\
\hline 3 & $\begin{array}{l}\text { What do you think of the balance } \\
\text { top-up menu display in the application? }\end{array}$ & \\
\hline 4 & $\begin{array}{l}\text { What do you think of the history menu display in the } \\
\text { application? }\end{array}$ & \\
\hline 5 & $\begin{array}{l}\text { What do you think of the promotions menu display in the } \\
\text { application? }\end{array}$ & \\
\hline 6 & $\begin{array}{l}\text { What do you think of the favorite services menu display in the } \\
\text { application? }\end{array}$ & \\
\hline 7 & $\begin{array}{l}\text { What do you think of the user's setting menu display in the } \\
\text { application? }\end{array}$ & \\
\hline 8 & What do you think of the chat menu display in the application? & \\
\hline 9 & $\begin{array}{l}\text { What do you think of the cart and payment menu display in the } \\
\text { application? }\end{array}$ & \\
\hline
\end{tabular}


10 What do you think of the search menu display in the application?

11 How was the process of logging into the system until verification?

12 How was the process of inputting personal data into the system?

13 How was the process of ordering a service?

14 How was the payment process?

15 How was the balance filling process?

16 How was the logout process?

17 How was your experience on contacting vendors and asking for information?

18 How was your experience on avoid mistakes when using the application?

19 How was your experience on booking feature in this application?

20 How was your experience on the promotion feature in this application?

21 How was your experience on the Chat feature in this application?

22 How was your experience on giving a rating and review features?

23 How was your experience on doing payment features through balances and top up balances?

24 How was your experience when using all the features and menus in the application?

The following UAT results are based on user evaluations and system tests directly. This questionnaire was distributed to 15 respondents and categorized into 3 parameter sections, namely user interface, system process flow, and application features. The result shows $25.8 \%$ gives a rating of $5 ; 45.7 \%$ gives a rating of 4 ; $28.3 \%$ gives a rating of 3 and $0.2 \%$ gives a rating of 2 . The results of the UAT can be shown in the Tables 3, 4, and 5 .

Table 3. The result of the UAT User Interface

\begin{tabular}{ccccrc}
\hline No & $1(\mathrm{Bad})$ & 2 (Poor) & 3 (Enough) & 4 (Good) & 5 (Excellent) \\
\hline 1 & 0 & 0 & 7 & 3 & 5 \\
2 & 0 & 0 & 6 & 7 & 2 \\
3 & 0 & 0 & 6 & 5 & 4 \\
4 & 0 & 0 & 5 & 7 & 3 \\
5 & 0 & 0 & 5 & 7 & 3 \\
6 & 0 & 0 & 5 & 5 & 5 \\
7 & 0 & 0 & 1 & 10 & 4 \\
8 & 0 & 0 & 3 & 5 & 7 \\
9 & 0 & 0 & 1 & 7 & 7 \\
10 & 0 & 0 & 5 & 5 & 5 \\
\hline
\end{tabular}


Table 4. The result of the UAT system process flow

\begin{tabular}{cccccc}
\hline No & $1(\mathrm{Bad})$ & 2 (Poor) & 3 (Enough) & 4 (Good) & 5 (Excellent) \\
\hline 11 & 0 & 0 & 7 & 6 & 2 \\
12 & 0 & 0 & 6 & 8 & 1 \\
13 & 0 & 0 & 5 & 8 & 2 \\
14 & 0 & 0 & 3 & 10 & 2 \\
15 & 0 & 0 & 5 & 7 & 3 \\
16 & 0 & 0 & 5 & 5 & 5 \\
17 & 0 & 0 & 3 & 6 & 6 \\
18 & 0 & 1 & 4 & 6 & 4 \\
\hline
\end{tabular}

Table 5. The result of the UAT Application features

\begin{tabular}{cccccc}
\hline No & $1(\mathrm{Bad})$ & 2 (Poor) & 3 (Enough) & 4 (Good) & 5 (Excellent) \\
\hline 19 & 0 & 0 & 5 & 6 & 4 \\
20 & 0 & 0 & 5 & 8 & 2 \\
21 & 0 & 0 & 4 & 7 & 4 \\
22 & 0 & 0 & 3 & 11 & 1 \\
23 & 0 & 0 & 4 & 5 & 6 \\
24 & 0 & 0 & 4 & 5 & 6
\end{tabular}

Total Percentage of UAT: 25,8\% excellent, $45,7 \%$ good, $28,3 \%$ enough, and $0.2 \%$ bad.

\section{CONCLUSION}

The conclusions that can be drawn from implementing the system are as follows: First, the design of beauty salon and barbershop information systems is conducted by making a general picture design, data flow diagrams, ERD, and PDM as the basic structure in developing a database system. Second, the stages of the implementation of the information systems are using the Java programming language assisted by the Android Studio IDE. They were used in order to develop customer-side applications on the Android platform and PHP programming language to develop a web platform for the admin and vendor in dealing with customers. The testing process is conducted by testing both the Android platform application and the website platform application directly. Third, the results of the questionnaire show the measurement of E-CRM performance towards the AndroidBased Beauty Salon and Barber Shop Geographic Information System which can be stated to be running well from the vendor and customer side..

\section{REFERENCES}

[1] Putra, I. P. W., \& Narayana, I. W. G. (2014). Rancang bangun sistem informasi geografis pemesanan taksi berbasis android. Jurnal Sistem dan Informatika (JSI), 8(2), 50-59.

[2] Yuwono, B., \& Aribowo, A. S. (2015, December). Sistem informasi geografis berbasis android untuk pariwisata di daerah magelang. In Seminar Nasional Informatika (SEMNASIF) (Vol. 1, No. 1). 
[3] Yunefri, Y., Devega, M., \& Kristanto, D. (2017, December). Geographic information system (gis) for culinary in pekanbaru using herversine formula. In IOP Conference Series: Earth and Environmental Science (Vol. 97, No. 1, p. 012042). IOP Publishing.

[4] Neene, V., \& Kabemba, M. (2017). Development of a mobile GIS property mapping application using mobile cloud computing. Development, $8(10), 57-$ 68.

[5] Kusnawi, K. (2013). Perancangan sistem informasi pemesanan meja dan makanan (studi kasus restoran ABC). Data Manajemen dan Teknologi Informasi (DASI), 14(1), 40.

[6] Aulia, R., Zakir, A., Dafitri, H., \& Siregar, D. (2017). Mechanism of food ordering in a restaurant using android technology. JPhCS, 930(1), 012030.

[7] Rosadi, D., \& Andriawan, F. O. (2016). Aplikasi sistem informasi pencarian tempat kos di kota bandung berbasis android. Jurnal Computech \& Bisnis, 10(1), 50-58.

[8] Afrina, M., \& Ibrahim, A. (2013). Rancang bangun electronic costumer relationship management (e-CRM) sebagai sistem informasi dalam peningkatan layanan perpustakaan digital fakultas ilmu komputer unsri. JSI: Jurnal Sistem Informasi (E-Journal), 5(2).

[9] Le Tan, T., \& Dai Trang, D. T. (2017). Successful factors of implementation electronic customer relationship management (e-CRM) on e-commerce company. American Journal of Software Engineering and Applications, 6(5), 121-127.

[10] Luarasi, T., Domi, A., Thomo, T., Kasaj, A., \& Baboci, E. (2014, September). cloud based communication in B2B model. In 2014 8th Asia Modelling Symposium (pp. 27-32). IEEE.

[11] Rosmawarni, N. (2017). Perancangan sistem rekomendasi untuk pengembangan aplikasi salon terpadu berbasis android. Jurnal Rekayasa Informasi, 6(1).

[12] Tukino. (2018). Rancang bangun sistem informasi customer relationship management (CRM) berbasis web. Computer Based Information System Journal, 06(01), 12-22.

[13] Prastya, I., Hidayatuloh, S., \& Hasanati, N. (2017). Rancang bangun i-crm (interactive customer relationship management) untuk jasa agen perjalanan wisata (studi kasus: PT Persada Duta Beliton). Studia Informatika: Jurnal Sistem Informasi, 10(1).

[14] Fandhilah, Dany Pratmanto, A. Fatakhudin. (2018). Rancang bangun sistem informasi e-booking ruang karaoke berbasis web (studi kasus: karaoke keluarga happy puppy ). Indonesian Journal on Software Engineering, 3(2), $68-76$.

[15] Devi Mawarni; Rinabi Tanamal. (2016). Rancang bangun sistem informasi pada salon skala menengah. Informatika dan Sistem Informasi, 2(1), 74-81.

[16] Sri Handayani, L. G., Piarsa, I. N., \& Suar Wibawa, K. (2015). Sistem informasi geografis pemetaan jalan desa berbasis web. CSRID (Computer Science Research and Its Development Journal), 6(3), 171. https://doi.org/10.22303/csrid.6.3.2014.171-181 
[17] Widnyana, I., Piarsa, I., \& Agung Cahyawan W., A. (2016). Aplikasi sistem informasi geografis bengkel di kota denpasar berbasis android. Merpati, 3(1), 23-30.

[18] Gautama, I. W. W., Putra, I. K. G. D., \& Sukarsa, I. M. (2016). Aplikasi pemetaan objek wisata pantai bali selatan berbasis android. Merpati, 4(1), 4351. 